\title{
Climatic records and linkage along an altitudinal gradient in the southern slope of Nepal Himalaya
}

\author{
Binod Dawadi \\ Kathmandu Center for Research and Education (KCRE) \\ Chinese Academy of Sciences-Tribhuvan University, Kathmandu Nepal \\ Central Department of Hydrology and Meteorology, Tribhuvan University, Kathmandu 44613, Nepal \\ (Email:dawadib@itpcas.ac.cn; dawadib@cdhmtu.edu.np)
}

\begin{abstract}
To validate the climatic linkages under different topographic conditions, observational climate data at four automated weather stations (AWS) in different elevations, ranging from $130 \mathrm{~m}$ asl. to $5050 \mathrm{~m}$ asl., on the southern slope of the Nepal Himalayas was examined. the variation of means and distribution of daily, 5-days, 10-days, and monthly average/sum of temperature/ precipitation between the stations in the different elevation was observed. Despite these differences, the temperatures records are consistent in different altitudes, and highly correlated to each other while the precipitation data shows comparatively weaker correlation. The slopes $(0.79-1.18)$ with $\left(\mathrm{R}^{2}>0.64\right)$ in the regression models for high Mountain to high Himalaya except in November and 0.56-1.14 $\left(\mathrm{R}^{2}>0.50\right)$ for mid-hill and high Mountain except January, December, June indicate the similar rate of fluctuation of temperature between the stations in the respective region. These strong linkages and the similar range of fluctuation of temperature in the different elevation indicate the possibilities of their use of lower elevation temperature data to represent the higher elevation sites for paleoclimatic calibration. However, the associations of precipitation between the stations at the different elevation are not as strong as the temperature due to heterogeneous topographical features and steep altitudinal contrast.
\end{abstract}

Key words: Nepal Himalaya, climate change, higher elevation, paleo-climatic calibration, linkage, altitudinal variation

Received: 1 January 2017

Revision accepted: 27 May 2017

\section{INTRODUCTION}

Proxy data, such as tree rings, play an important role in understanding past climatic change (Bradley and Jones 1992). Data from these archives are generally calibrated with instrumental climate records to quantify their climatic sensitivities and subsequently used to reconstruct climate prior to the instrumental era (Fritts 1976). Instrumental records are often not available at the higher situated areas of the Himalayas, a climate-sensitive area. In the Himalayas, most of the meteorological stations are located in the low river valleys (Lang and Barros 2002, Böhner 2006), whereas climatesensitive forest sites are always located at high elevations. Thus, it is very difficult to develop climate vs. tree-ring calibration model to reconstruct past climate in the Himalayas (Cook et al. 2003; Sano et al. 2005; Yadav et al. 2011; Dawadi et al. 2013; Liang et al. 2014). The steep S-N gradient and complex topography results in higher variations of climate within a short distance in the southern slope of the central Himalayas. Many studies (Nayava 1980; Putkonen 2004; Dhar and Nandargi 2005; Ichiyanagi et al. 2007; Barry 2008) found an increase in precipitation with increasing altitude up to a certain elevation and begin to decrease with increasing elevation. However, the altitude of the maximum precipitation belt varies in the central Himalayas. For example, the maximum precipitation belt is located around $1000-1700 \mathrm{~m}$ asl in western Nepal (Kansakar et al. 2004; Dhar and Nandargi 2005), $3200 \mathrm{~m}$ asl in west central Nepal (Putkonen 2004), 1600-2600 m asl in the Langtang region of central Nepal (Fujita et al. 2006) and at $1400 \mathrm{~m}$ asl in Kanchanjangha area of eastern Nepal (Dhar and Nandargi 2000). Barros et al. (2000), as well as Lang and Barros (2002), noted significant spatial variability in monsoon precipitation (4 times differences within $10 \mathrm{~km}$ distance). Bookhagen and Burbank (2006) investigated the relationship between precipitation and topography in the Himalayas from the precipitation radar (PR) onboard the Tropical Rainfall Measuring Mission (TRMM). They discovered the strong large-scale relationships among topography, relief, and rainfall location with two distinct rainfall maxima around at $950 \mathrm{~m}$ asl and $2100 \mathrm{~m}$ asl respectively. Recently, Duncan et al. (2013) illustrated a spatial variation in the monsoon precipitation with east-west and north-south gradients. These results confirmed the spatial, temporal and altitudinal variations of precipitation, which may influence the seasonal temperature trends in Nepal (Shrestha et al. 1999).

In temperature trend analysis Shrestha et al. (1999) found a higher rate $\left(0.06-0.12^{\circ} \mathrm{C} / \mathrm{year}\right)$ of increase in the maximum temperature at higher elevations whereas no trend or even cooling trend was observed at lower elevations. Sharma 
et al. (2009) and Kattel and Yao (2013) also reported the strong warming trend at higher elevations of the Himalayas. The marked altitudinal range of the country has resulted in significant spatial variation of temperature in Nepal (Shrestha and Aryal 2011).

Meteorological stations near the proxy source are always preferable for the paleo-climatic calibration. However, in the Nepal Himalayas, most of the meteorological stations are located in the lower elevation and far from the proxy sources. Till date, whether the variation in the instrumental climatic records from the meteorological stations from the lower elevation is representative for the climate of high elevation is a question not having received the attention it deserves, given the importance of the calibration process for the paleo-climatic reconstructions. Therefore, the objective of this paper is to determine/quantify the linkages of climatic records along an altitudinal gradient from $130 \mathrm{~m}$ asl to $5050 \mathrm{~m}$ asl in the southcentral Himalayas. It is hypothesized that temporal variations in temperature at different elevations have good homogeneity, while precipitation displays large spatial heterogeneity.

\section{STUDY AREA}

A mountainous country Nepal in the central Himalayas occupies one fourth of the expanse of the Himalayas and bordered with India on three sides and Tibet of People's Republic of China to the north. It is situated between $26^{\circ} 22$ to $30^{\circ} 27^{\prime} \mathrm{N}$ and $80^{\circ} 04^{\prime}$ to $88^{\circ} 12^{\prime} \mathrm{E}$, orienting roughly parallel to the axis of Himalayas. The east-west length of the country is approximately $800 \mathrm{~km}$, while the north-south width varied from east to west and around $200 \mathrm{~km}$ on average. Altitude varies from $60 \mathrm{~m}$ asl above the sea level to $8848 \mathrm{~m}$ asl at Mt. Everest, the highest point in the world. Nepal is divided into five major physiographical regions:

1. Terai $(60-300 \mathrm{~m})$ : The Terai is a flat and valuable stretch of fertile agricultural land in southern Nepal, which forms a part of the alluvial Gangetic plain. This region extends $\sim 800 \mathrm{~km}$ from east to west and 30-40 km north to south and covers $14 \%$ of the total area of the country. This region has a subtropical climate usually very hot summer.

2. Siwalik Hills (700-1500 m): The Siwalik Hills rise abruptly from the Terai plain and extend from east to west, being wider in western regions than the eastern $(8-12 \mathrm{~km})$. This region covers nearly $13 \%$ of the total area of the country and characterizes by low terraces with steep topography and subtropical climate.

3. Middle Mountains (1500-2700 m): Running parallel to the north of the Siwalik range, the Middle Mountains (also known as the middle hills) extend throughout the length of the country. The mid hill region covers $\sim 30 \%$ of the total area of the country. It is the first great barrier to the monsoon wind that produces the highest precipitation on its southern slopes due to orographic effects. The climate of this region ranges from sub-tropic in the valley bottom to cool temperate on the higher ridges.
4. High Mountains (2700-4000 m): The high Mountain region lies further north of the middle Mountain range and covers about the $20 \%$ area of the country. It has an average width of $50 \mathrm{~km}$ and extends from east to west. Steep slopes and narrow valleys with cool alpine climate characterize this region.

5. High Himalayas (4000-8848 m): This region is along the northern boundary of the monsoon climate and geopolitical border between Nepal and China. This zone is an area of rocky, ice-covered massifs, rolling upland, snowfields, alpine glaciers, and sweeping meadow-lands. Eight of the ten highest peaks exceeding $8000 \mathrm{~m}$ on earth, including the Mt. Everest ( $8848 \mathrm{~m}$ ), are located in the high Himalayas. Alpine and Tundra climate exists in this region and covers $\sim 23 \%$ of the total area of the country.

In this study, four observational stations Simara, Kathmandu, Kyangjing and Pyramid earth station are selected (Fig 1) on the basis of the following criteria: (a) representatives to different physiographical regions of Nepal (b) altitudinal difference between the stations more than $1000 \mathrm{~m}$ and (c) the Automated Weather Stations (AWS) data available for the period of 20052010 AD. The climate of the study area is characterized by strong summer monsoon from mid-June to September and by westerlies in the winter (December of the previous year, January, February). Monthly variations of temperature and precipitation based on the long-term averages showed that July is the month with highest precipitation except in Pyramid (August) and the hottest except Simara (June) (Fig. 2). The annual average temperature ranges from $14.5^{\circ} \mathrm{C}$ to $29.7^{\circ} \mathrm{C}$ in Simara, $11^{\circ} \mathrm{C}$ to $23.8^{\circ} \mathrm{C}$ in Kathmandu, $-2^{\circ} \mathrm{C}$ to $10.4^{\circ} \mathrm{C}$ in Kayngjing and $-8.5^{\circ} \mathrm{C}$ to $3.5^{\circ} \mathrm{C}$ in Pyramid. With increasing elevations, annual precipitation is $1903 \mathrm{~mm}, 1533 \mathrm{~mm}, 681 \mathrm{~mm}$, and $406 \mathrm{~mm}$ from Simara, Kathmandu, Kyangjing to Pyramid, respectively. These regions receive the highest precipitation ( $>78 \%)$ during the monsoon season (June-September) and the least $(<4 \%)$ in winter.

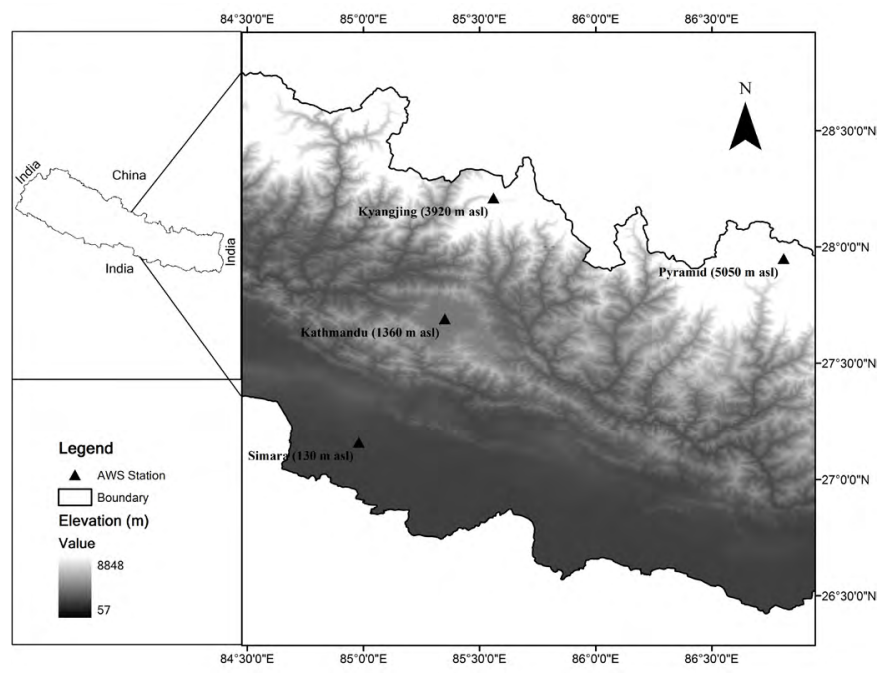

Fig. 1: Map of Nepal (inset) showing the automatic weather stations (AWS) in different physiographical regions. 

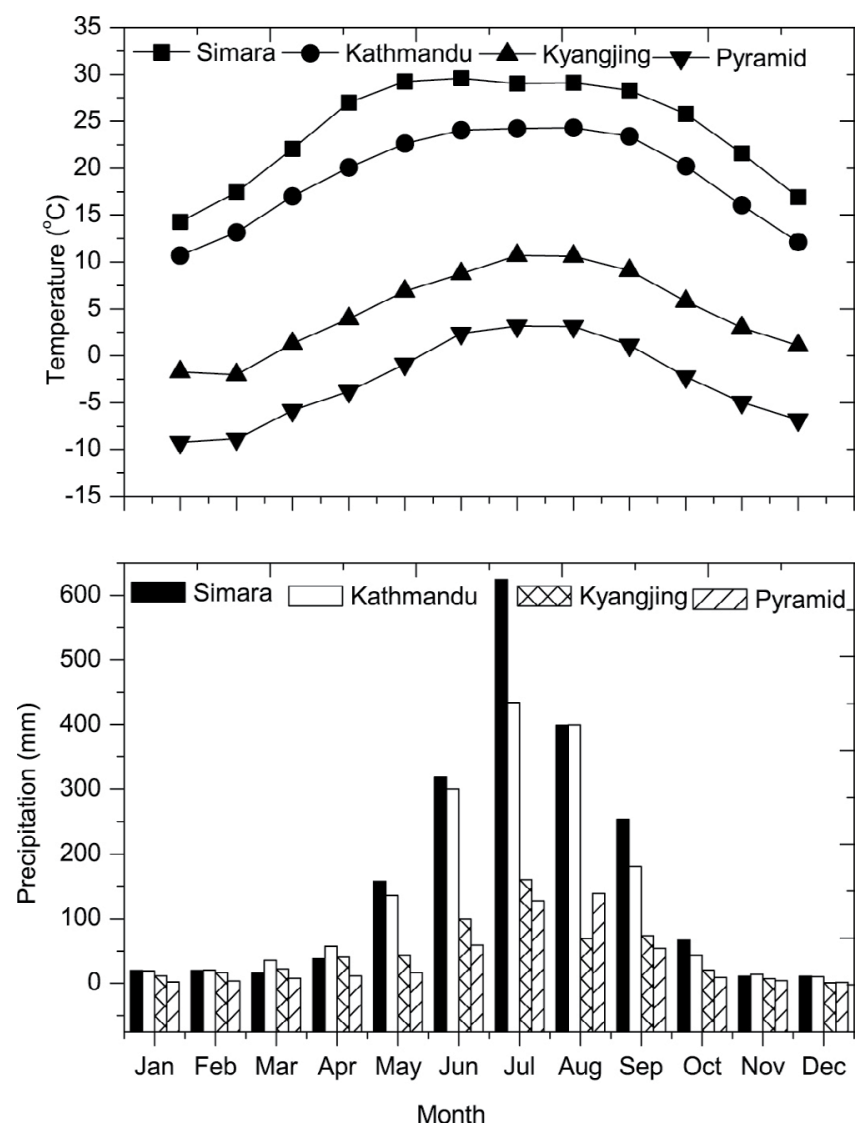

Fig. 2: Monthly temperature and precipitation variation in the study area (1994-2010).

\section{DATA SOURCE AND METHODS}

The climatic data for the station Simara (Terai plain), Kathmandu (mid hill), Kyangjing (high mountain) were collected from the Department of Hydrology and Meteorology (DHM), Government of Nepal and data of Pyramid (high Himalaya) was taken from Everest K2 Consiglio Nazionale delle Ricerche Italia (EV-K2-CNR, Italy). These data were collected from only AWSs. The AWSs are composed of data loggers manufactured by campbell CR 1000 .

LSI-Lastem DMA572 and LSI-Lastem DQA035 sensors were used for temperature and precipitation respectively. These sensors can measure the temperature in the range from $-30^{\circ} \mathrm{C}$ to $+70^{\circ} \mathrm{C}$ with $\pm 0.1^{\circ} \mathrm{C}$ accuracy and $180 \mathrm{~mm} / \mathrm{hr}$ measurement range for precipitation. These automatic weather stations take hourly measurements for temperature and precipitation. The daily, 5-days, 10-days and monthly records of the mean temperature and sum of precipitation from the AWSs at the different meteorological stations were compared to each other during the period of January 2005 to December 2010. Their mean values were checked by paired sample t-tests, the data distributions by two-sample Kolmogorov-Smirnov tests, standard deviation and Pearson's correlations are used to measure the strength of the relationships among the temperature/precipitation records. To quantify the relationships of climatic records between low and high elevations, regression analyses were performed on the daily mean temperature and daily precipitation by months. The intercepts and slopes of the regression models, together with the R-square values, are used to evaluate the physical meanings and quality of the regression models, as shown by Liang et al. (2011). To confirm the patterns seen in the daily data, we also performed the regression analyses on the 5-days/10-days/ monthly mean temperature and total precipitation data. In order to understand the magnitude of seasonal co-variation in average temperature and sum of precipitation between the stations at different elevations, we pooled data from 5-days mean/sum of temperature/precipitation for the individual season. The four seasons are divided as winter, pre-monsoon (March-May), monsoon, post-monsoon (October-November).

\section{RESULTS}

\section{Association of temperature records between meteorological stations}

Data distribution and means of temperatures in the different stations at the elevational gradient are quite different. The paired T-test confirmed that daily, 5-days, 10-days and monthly averages of temperature from 2005 to 2010 are significantly different between the stations in the higher elevation with their corresponding lower elevation Two-sample KolmogorovSmirnov Test also showed the significant differences in continuous distributions in the same above analyzed periods (Table 1). Temperature difference between the stations SimaraKathmandu, Kyangjing-Pyramid and Pyramid-Simara was found highest in April where as Kathmandu-Kyangjing showed the highest temperature difference in the month of March. Similarly, all the stations showed the minimum temperature difference in the month of December except for SimaraKathmandu (November). The temperature difference was higher in pre-monsoon season whereas we found a minimum difference in early winter season (Fig. 3). It increases from December to May and gradually decreases with increasing cloudiness associated with onset of monsoon.

In spite of differences at their absolute values, variations of temperature records at different elevations are consistent to each other. The correlations of mean temperatures between the stations range from 0.48 to $0.87(\mathrm{p}<0.001, \mathrm{n}=2191)$, for daily, 0.55 to $0.93(\mathrm{p}<0.001, \mathrm{n}=438)$ for 5 -days, 0.57 to 0.94 $(\mathrm{p}<0.001, \mathrm{n}=219)$ for 10 -days and 0.66 to $0.96(\mathrm{p}<0.001, \mathrm{n}=72)$ for monthly data series (Fig. 4). The strength of correlation increases with increasing time window. The seasonal analysis of temperature between Kathmandu-Kyangjing and Kyangjing-Pyramid showed strong and significant correlation $(r=0.54-0.97, p<0.001)$ in all seasons. However, the weaker correlation exists between Simara - Kathmandu and PyramidSimara (Table 2).

\section{Using low-elevation data to represent high elevation temperature}

Fig. 5 represents the intercepts, slopes and R-square values of regression analysis of the higher elevation data against their corresponding lower elevation data for daily and 5-days data pooled by individual months. Based on the results of 
Table 1: Average and standard deviation of daily, 5-days, 10-days and monthly temperature and precipitation at different stations during the period of January 2005 to December 2010. Average temperature is in ${ }^{\circ} \mathrm{C}$ and average sum of precipitation .

\begin{tabular}{|l|l|l|l|l|}
\hline Parameters & $\begin{array}{l}\text { Average/std dev } \\
\text { Simara }\end{array}$ & $\begin{array}{l}\text { Average/std dev } \\
\text { Kathmandu }\end{array}$ & $\begin{array}{l}\text { Average/std dev } \\
\text { Kyangjing }\end{array}$ & $\begin{array}{l}\text { Average/std dev } \\
\text { Pyramid }\end{array}$ \\
\hline Daily temperature & $22.8 / 7.2$ & $17.7 / 5.9$ & $3.4 / 4.9$ & $-2.1 / 4.6$ \\
\hline 5-days temperature & $22.9 / 6.5$ & $17.7 / 5.7$ & $3.5 / 4.8$ & $-2.1 / 4.4$ \\
\hline 10-days temperature & $22.9 / 6.1$ & $17.8 / 5.6$ & $3.6 / 4.7$ & $-2.0 / 4.2$ \\
\hline Monthly temperature & $22.8 / 5.7$ & $17.7 / 5.4$ & $3.4 / 4.6$ & $-2.1 / 4.0$ \\
\hline Daily precipitation & $5.1 / 17.8$ & $3.4 / 9.3$ & $2.1 / 5.1$ & $1.1 / 2.6$ \\
\hline 5-days precipitation & $25.5 / 59.1$ & $18 / 28.2$ & $10.6 / 17$ & $4.3 / 9.2$ \\
\hline 10-days precipitation & $50.9 / 98.7$ & $25.9 / 46.4$ & $21.2 / 27.3$ & $9.0 / 17$ \\
\hline Monthly precipitation & $152.6 / 217.6$ & $107.6 / 117.4$ & $62.1 / 69.9$ & $24.0 / 41.1$ \\
\hline
\end{tabular}

Table 2: Seasonal correlation of temperature between the stations; Sim, Ktm, Kyn, and Pyd represent the name of station as Simara, Kathmandu, Kyangjing and Pyramid respectively. Significant correlations are indicated at $* * p<0.01$ and $* p<$ 0.05.

\begin{tabular}{|l|l|l|l|l|}
\hline Season & Sim-Ktm $($ Cor $/ \mathbf{n})$ & Ktm-Kyn $($ Cor $/ \mathbf{n})$ & Kyn-Pyd $($ Cor/n) & Pyd-Sim $($ Cor $/ \mathbf{n})$ \\
\hline Winter & $* 0.23 / 109$ & $* * 0.59 / 109$ & $* * 0.65 / 109$ & $*_{-} 0.26 / 109$ \\
\hline Pre-Monsoon & $* * 0.57 / 108$ & $* * 0.59 / 108$ & $* * 0.85 / 108$ & $* * 0.46 / 108$ \\
\hline Monsoon & $* * 0.68 / 144$ & $* * 0.82 / 144$ & $* * 0.97 / 144$ & $* * 0.54 / 144$ \\
\hline Post-Monsoon & $* * 0.59 / 72$ & $* * 0.85 / 72$ & $* * 0.76 / 72$ & $* * 0.37 / 72$ \\
\hline
\end{tabular}

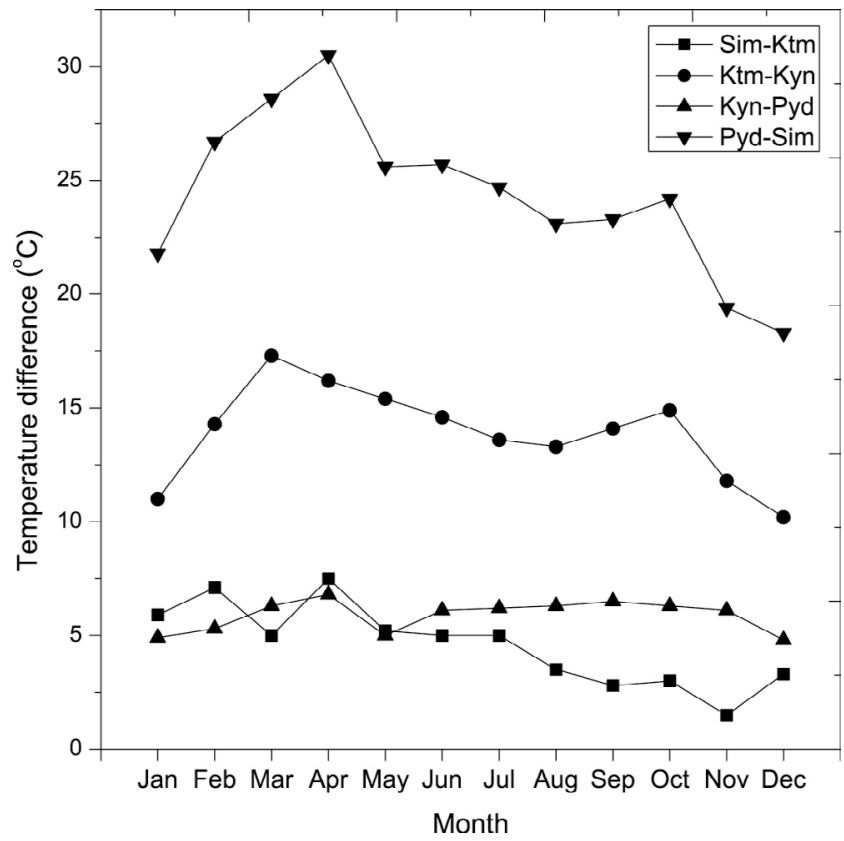

Fig 3: Differences of the monthly mean temperature between stations. SIM, KTM, KYN, PYD represent the stations Simara, Kathmandu, Kyangjing and Pyramid respectively.

regression, it is clear that the variations in the daily and seasonal temperatures at lower elevations are excellent representatives for their counterparts at nearby higher elevations, supporting our hypothesis. The intercept of the regression model indicates a hypothetical 'base temperature' at a higher elevation when the corresponding lower elevation temperature is $0^{\circ} \mathrm{C}$.
The slopes of the model, however, showed the amount of temperature changes at higher elevation per ${ }^{\circ} \mathrm{C}$ measured at the corresponding lower elevation.

It is interesting to note that for every $1^{\circ} \mathrm{C}$ change of temperature in Kathmandu, Kyangjing temperature changed by 0.56 to $1.14^{\circ} \mathrm{C}$ except in June $\left(0.29^{\circ} \mathrm{C}\right)$. During the winter season, the changing rate of Kyangjing temperature in corresponding to Kathmandu is $>0.84 / 1^{\circ} \mathrm{C}$ whereas comparatively lower $\left(<0.64 / 1^{\circ} \mathrm{C}\right)$ in the monsoon season. $\mathrm{R}^{2}$ values of the regression model are relatively high $(>0.51)$ except January, December, and June. Temperature between Kyangjing and Pyramid (High Himalayas) showed the almost similar range of fluctuation throughout the year. For $1^{\circ} \mathrm{C}$ change in Kyangjing there is 0.77 to $1.18^{\circ} \mathrm{C}$ change in temperature at Pyramid except for November $\left(0.49^{\circ} \mathrm{C}\right)$. Higher slopes $(>1.0)$ in January, April, May, August, and September indicated higher fluctuations of temperature in Pyramid in comparison with Kyangjing. $\mathrm{R}^{2}$ values of the regression model are also high $(>0.64)$ except in November. However, the temperature data in Simara cannot represent well for Kathmandu and Pyramid.

\section{Comparison of precipitation along the altitudinal gradient}

Precipitation shows spatial and temporal variability along the altitudinal gradient. The daily, 5-days, 10-days and the monthly sum of precipitation are significantly different between the stations and decrease with increasing elevation along the S-N transects (Table 1). However, they are significantly correlated to each other. Their correlations increase with increasing time window from $0.18-0.30$ for daily data to 0.55 - 
a) Sim-Ktm

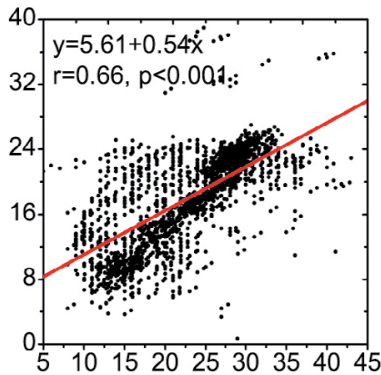

b) Ktm-Kyn

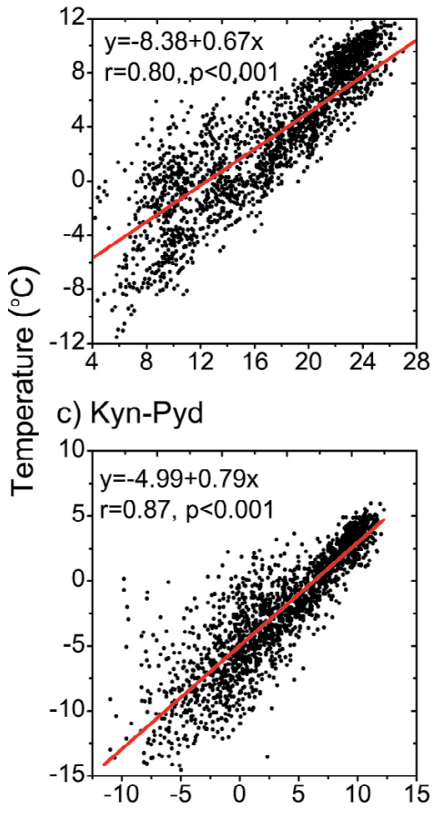

d) Pyd-Sim

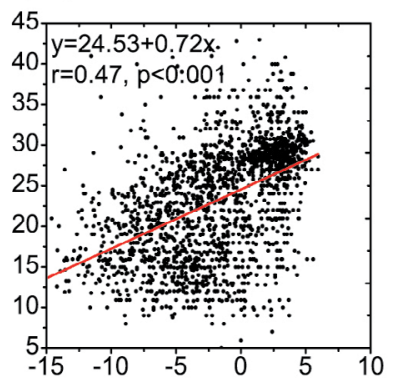

5-day
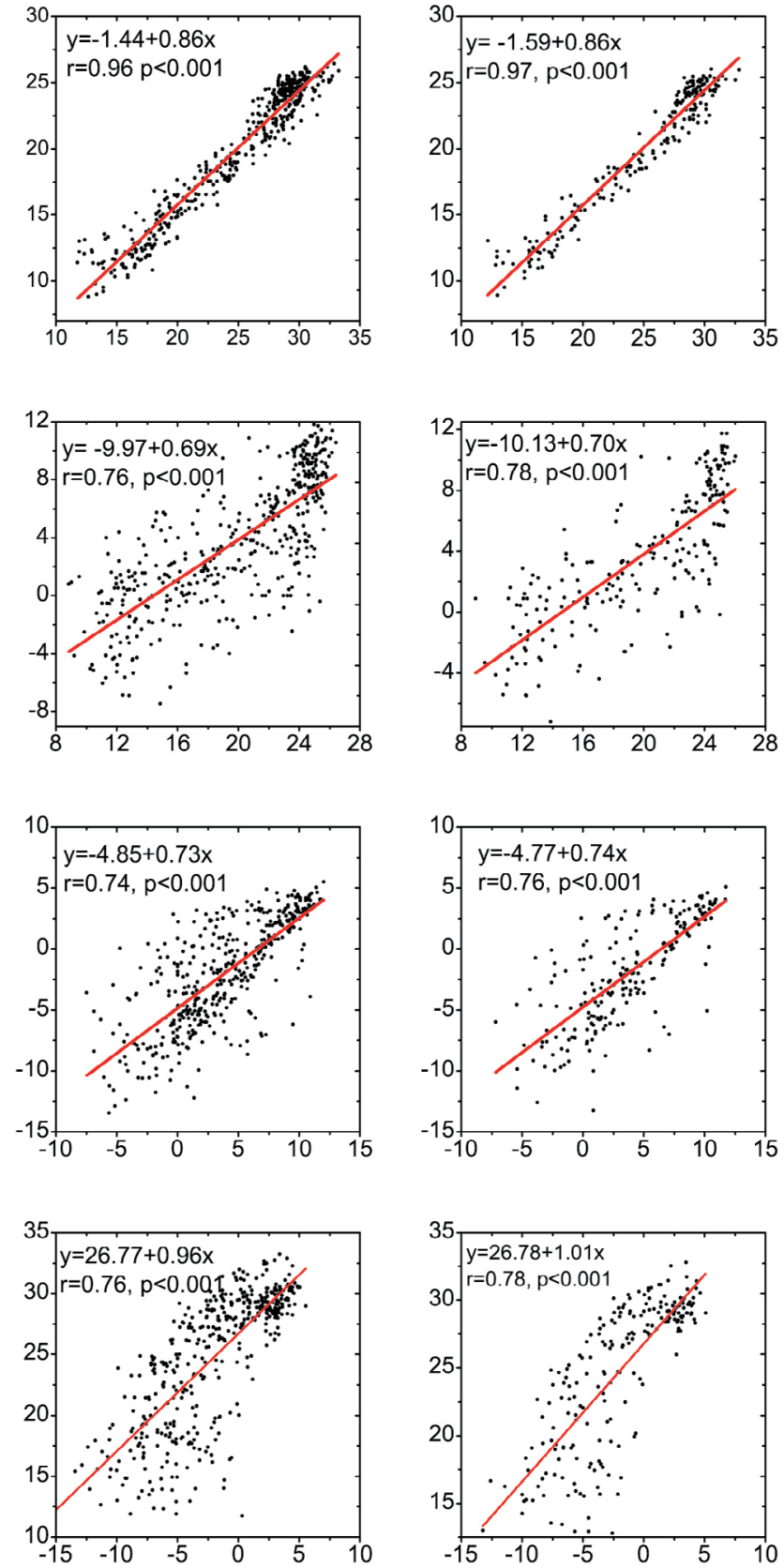
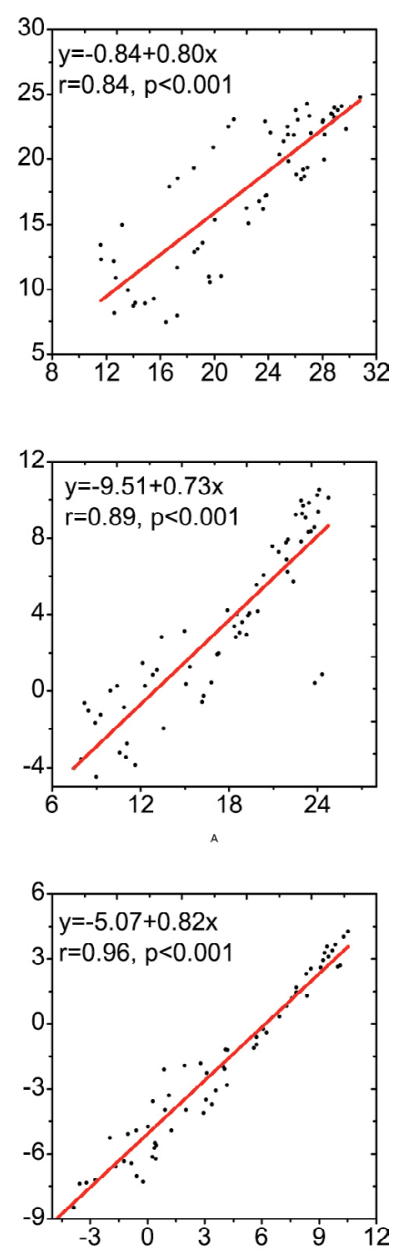

Monthly

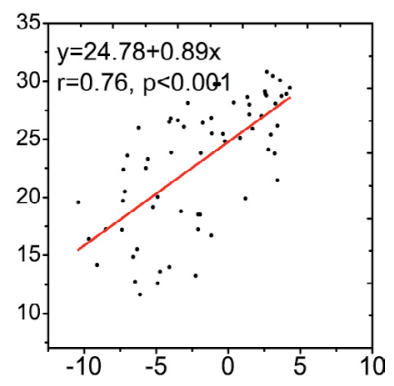

Temperature $\left({ }^{\circ} \mathrm{C}\right)$

Fig. 4: A scatter plot for the daily, 5-days, 10-days and monthly mean temperature between stations (a) Simara and Kathmandu, (b) Kathmandu and Kyangjing (c) Kyangjing and Pyramid (d) Pyramid and Simara.

0.81 for the monthly sum of precipitation $(\mathrm{p}<0.001)$ (Fig. 6). The seasonal correlation of precipitation between the stations in the Terai/mid hills and mid hills/high mountains are positive and significant $(\mathrm{p}<0.05)$ to each other for all the seasons (Table 3). However, precipitation between Kyangjing-Pyramid and Pyramid-Simara is weak and insignificant in most of the seasons. When precipitation data are added up in the different months for regression analyses, the intercepts of the regression models give actual physical meaning. The intercepts represent the amount of precipitation at lower elevation when there is no precipitation record on the corresponding high elevation stations. When there was no precipitation in Kathmandu, we found $34 \mathrm{~mm}$ rainfall in Simara. Similarly, Kathmandu received up to $26 \mathrm{~mm}$ rainfall when there is no precipitation recorded in the corresponding high elevation station at Kyangjing and 18 $\mathrm{mm}$ precipitation at Kyangjing when there is no precipitation at the corresponding high elevation station at Pyramid (Fig. 7). The high intercept values were generally found during the monsoon season, clearly showed the influence of summer monsoon rainfall originated from the Bay of Bengal. 
Dawadi, $B$.

Table 3: Seasonal correlation of precipitation between the stations; Sim, Ktm, Kyn, and Pyd represent the name of station as Simara, Kathmandu, Kyangjing and Pyramid respectively. Significant correlations are indicated at $* * p<0.01$ and *p< 0.05.

\begin{tabular}{|l|l|l|l|l|}
\hline Season & Sim-Ktm $($ Cor $/ \mathbf{n})$ & Ktm-Kyn $($ Cor $/ \mathbf{n})$ & Kyn-Pyd $($ Cor $/ \mathbf{n})$ & Pyd-Sim $($ Cor $/ \mathbf{n})$ \\
\hline Winter & $* * 0.39 / 109$ & $* * 0.57 / 109$ & $0.13 / 109$ & $-0.00 / 109$ \\
\hline Pre-Monsoon & $* * 0.56 / 108$ & $* 0.21 / 108$ & $-0.08 / 108$ & $-0.02 / 108$ \\
\hline Monsoon & $* 0.19 / 144$ & $* * 0.29 / 144$ & $0.11 / 144$ & $* 0.2 / 144$ \\
\hline Post-Monsoon & $* * 0.41 / 72$ & $* * 0.88 / 72$ & $0.04 / 72$ & $0.07 / 72$ \\
\hline $\mathrm{n}$ is in mm. & \multicolumn{3}{|l}{} \\
\hline
\end{tabular}

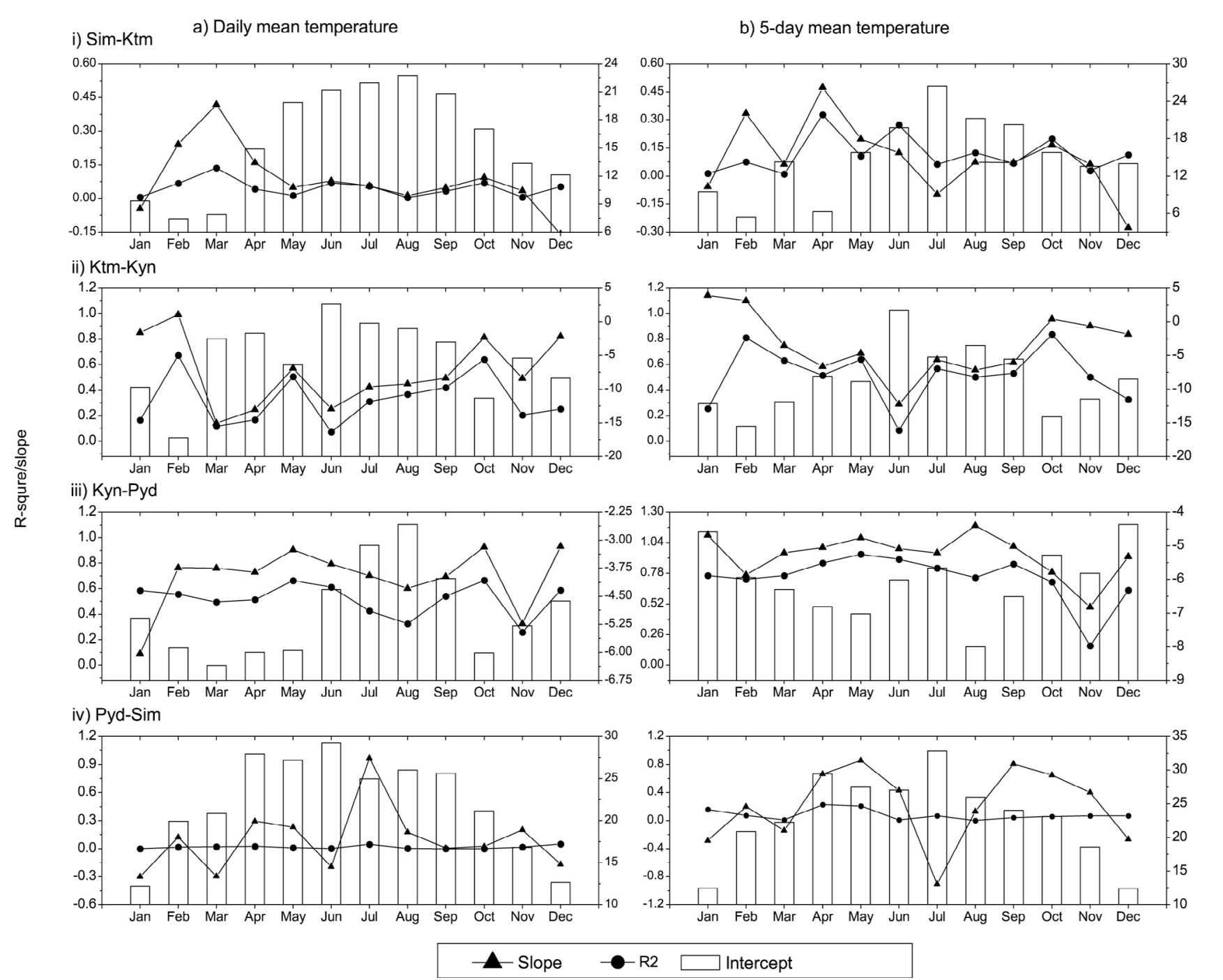

Fig. 5: Intercepts, slopes and $\mathbf{R}^{2}$ values of regression models by months between the different stations, Regression models using the (a) daily mean temperature (b) 5-days mean temperature. Sim. Ktm, kyn, Pyd represents the stations Simara, Kathmandu, Kyanging and Pyranid respectively.

\section{DISCUSSION}

\section{Association of temperature records between meteorological stations}

Strong and significant correlations were observed between Kyangjing and Pyramid as well as between the Kathmandu and Pyramid except for November and June respectively. Strong correlations of temperature between high-elevation stations (Kyangjing and Pyramid) might be due to their similarities in topographical condition, cloud cover, snow cover and wind pattern (Pepin and Norris 2005). At high elevations, temperature variability is closely related with snow cover at the beginning of the winter season (Ueno and Aryal 2008). At the high Himalayas (Pyramid), there is always snow cover in November but at Kyangjing (High Mountain), the temperature never reaches to $0^{\circ} \mathrm{C}$ during this month, (Fig. 2) 

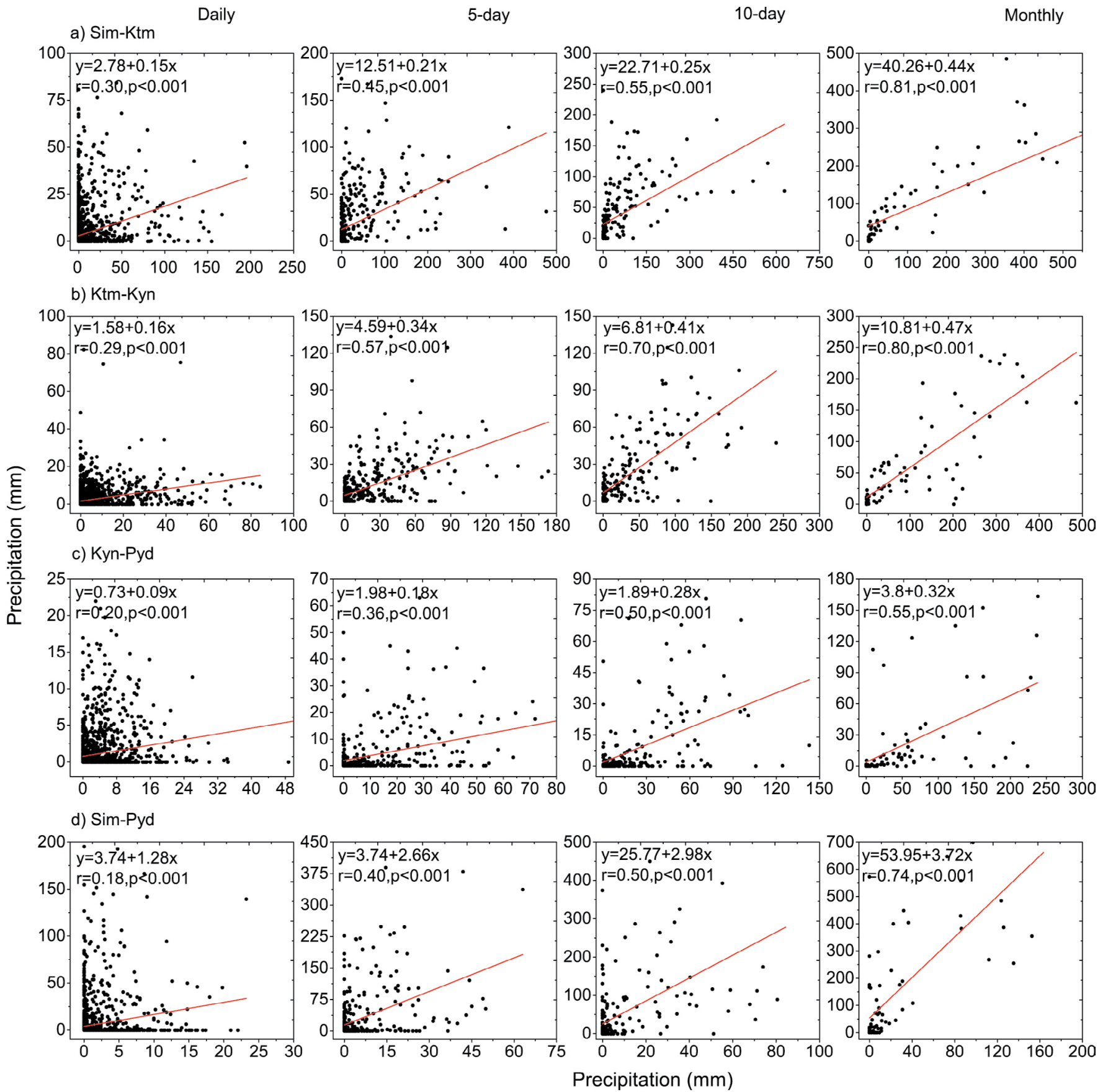

Fig. 6: A scatter plot for the daily, 5-days, 10-days and monthly sum of precipitation between stations. (a) Simara and Kathmandu, (b) Kathmandu and Kyangjing (c) Kyangjing and Pyramid (d) Pyramid and Simara.

resulting inconsistent temperature variations in the particular month (Fig. 5). The mid hills are the first great obstacles for summer monsoon that often onsets in mid-June (Shrestha et al. 2000). Thus, the onset of monsoon and associated cloudiness in the south and comparatively dry and fair weather in the north might be the reason for large variation of temperature in June between the stations in mid hill and high Mountain (Kathmandu-Kyangjing). In general, the heating of the atmosphere induces a valley wind over the slope of a mountain generate horizontal pressure gradient and creates the local level inversion. However, the plain areas have a wide variety of weather throughout the year, with cold winter and very hot summer causes inconsistency in temperature variation between the plain areas with those of hills or mountain areas. In the mountain region, when the sun is shining, it may be quite warm, even in winter, but if a passing cloud blocks the sun, the temperature drops rapidly. The thin and clean sub-alpine air does not hold heat well and allows a larger magnitude of solar radiation back and forth to the surface (http://snobear.colorado. edu/Markw/Mountains/03/mtn_04DRAFT2.doc). This might be the reason for the high degree of fluctuation in temperature in the winter season in the high Mountain region in comparison with the mid hills (Fig. 4). Extreme climatic events, such as extreme dry winter (precipitation $30 \%$ below the normal) from 
November 2005 to January 2006, could weaken the linkage of temperature records between the stations at low and high elevations. Such a dry climate caused less snow cover in the high Himalayan region. Reductions in snow cover at high elevations will alter the surface energy balance at the local level and hence increase the surface air temperature (Ueno and Aryal 2008). As a result, the February temperature at Kyangjing became positive for the third time in 2006 since the observation begins (1989). Another case is wetter winter from February to March 2007, also bringing a light snowfall on February 14 for the first time in the past 62 years in Kathmandu (DHM 2007). Such an extreme climatic events during our analysis period caused weaker climatic correlations between the snowcovered area and snow-free area (Kathmandu-Kyangjing,
Pyramid-Simara) as well as the valley and plain areas (SimaraKathmandu). Monsoonal circulations influence the seasonal temperature in Nepal (Shrestha et al. 1999) and the summer monsoon system is the most predominant weather system in giving rise to precipitation (Shrestha 2000). Therefore, when summer monsoon is active throughout the country during the monsoon season, high correlation of temperature between stations in different altitude is observed. The pre-monsoon and post-monsoon seasons are characterized by clear sky and gradually increase/decrease in temperature throughout the country. Therefore, these two seasons also showed significant and stronger correlations between the stations in the different altitude (Table 2).
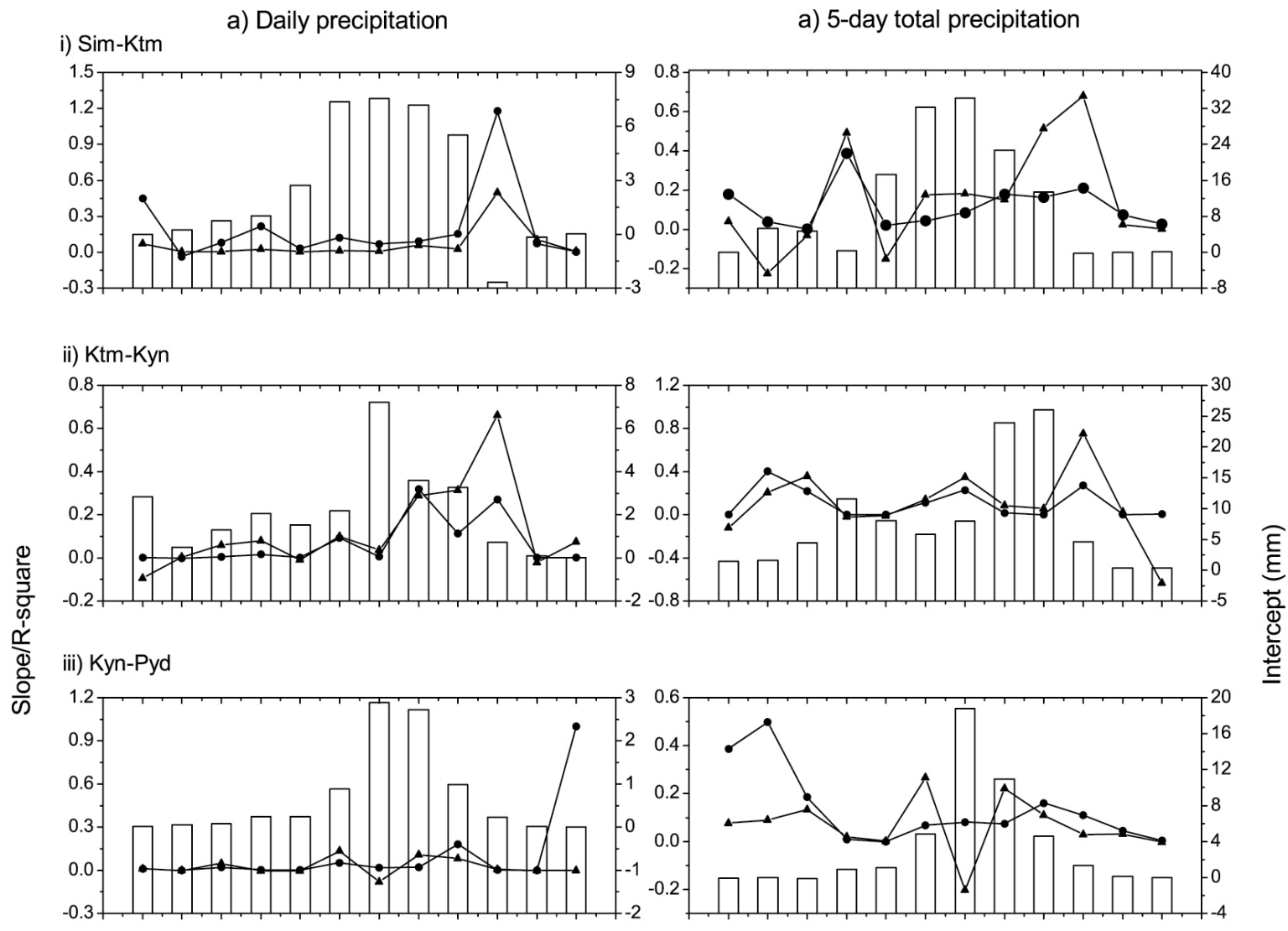

iv) Pyd-Sim
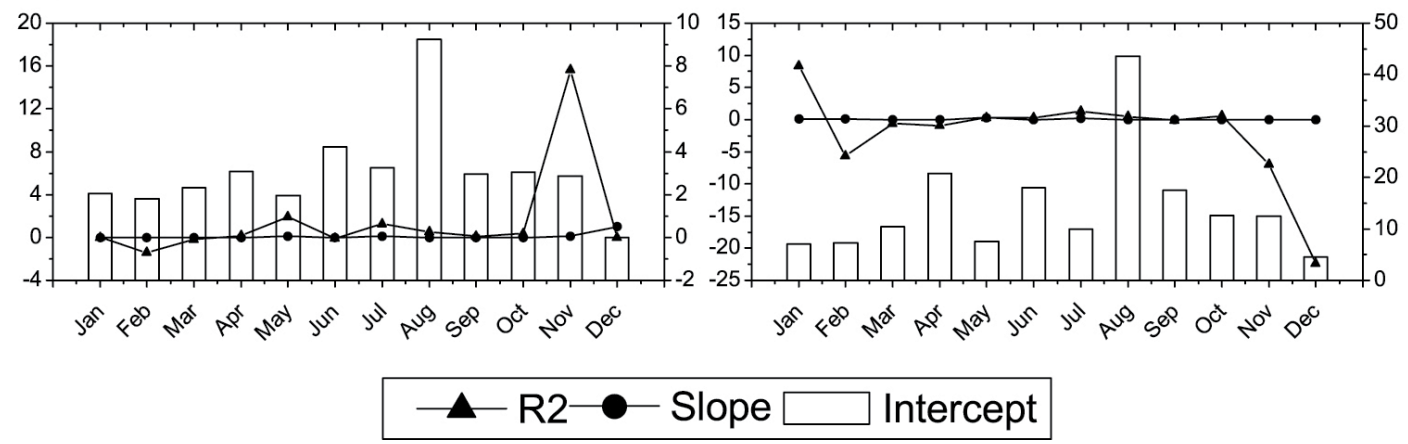

Fig. 7: Intercepts, slopes and $\mathbf{R}^{2}$ values of regression models for precipitation by months between the different stations, Regression models using the (a) daily precipitation (b) 5-days total precipitation. Sim, Ktm. Kyn, and Pyd represent the stations Simara, Kathmandu, Kyangjing and Pyramid, respectively. 


\section{Precipitation variation between stations}

Precipitation of a place depends upon several factors such as topography, a strength of moisture-bearing wind, the orientation of the mountain range with respect to the prevailing wind direction. The heterogeneous features of topography along with steep altitudinal contrast in Nepal play an important role in precipitation process and its distribution (Shrestha 2000). A large change in elevation within a relatively short distance causes a great difference in precipitation in Nepal (Higuchi et al. 1982; Shrestha et al. 2000; Lang and Barros 2002). Many studies (Singh and Kumar 1997; Barros et al. 2000; Kansakar et al. 2004; Anders et al. 2006; Ichiyanagi et al. 2007; Duncan et al. 2013) concluded that orography and the spatial arrangement of topographic gradients control the precipitation patterns over Nepal and their effects are more pronounced in summer (Shrestha 2000; Barros et al. 2004) resulting inconsistency and weak correlation of precipitation between the stations in different altitude. In the high-elevation annual precipitation is much lower in lee-side than in windward side (Kansaker et al. 2004; Putkonen 2004; Dhar and Nandargi 2005). Increase in total/summer precipitation from lower to higher elevation up to a certain point (Nayava 1980; Dhar and Nandargi 2000; Putkonen 2004) followed by decrease with increasing elevation (Barry 2008) and increase in winter precipitation with increasing altitude (Putkonen 2004), making wide variation in precipitation between the stations at different elevations. Analyzing the TRMM data Shrestha et al. (2012) showed two high-rainfall zones for monsoon rainfall, one around $600 \mathrm{~m}$, and another around $2100 \mathrm{~m}$ with different rain mechanism. Lower elevation receives high rainfall as a result of few heavy rainfall events, whereas the higher altitude receives high rainfall as a result of the high frequency of relatively weak but persistent rainfall. This difference in rainfall mechanism in different altitude also weakens the monthly and seasonal precipitation along the altitudinal gradient in the southern slope of central Himalayas. Along with these factors, occasionally occurring extreme climatic events (as described earlier) weakened the association of precipitation between different elevations and not stronger as temperature distribution.

\section{CONCLUSIONS}

In order to investigate the climatic linkage between stations in different elevation, we compared the climatic data representing wide range of topographical features from Plain area (130 $\mathrm{m}$ asl) to the high Himalaya (5050 $\mathrm{m}$ asl) during the period of January 2005 to December 2010 AD. In terms of magnitude, their means and distributions, temperature and precipitation in the different altitude at varying time scales are significantly different to each other. Despite of these differences, the variation of temperature and precipitation are consistent between the stations in the different altitude and their agreement increase with increasing time window. Strong and significant correlation of temperature was observed between the stations in the different elevation (except between Simara-Kathmandu and Pyramid-Simara). The slopes of the regression model $\sim 1$ with $\left(\mathrm{R}^{2}>0.5\right)$ indicate the similar change in temperature between the stations at higher elevation to the corresponding lower elevation station. As commonly used variable for calibration in dendroclimatic studies monthly temperature records at the lower elevation was better representative for the corresponding station at the higher elevation, however some corrections are necessary when absolute values of temperature is considered. Precipitation data also show a similar pattern, however; the associations between the stations at the different elevation are not as strong as the temperature due to heterogeneous topographical features and steep altitudinal contrast, supporting our hypothesis. This study represents a further step towards understating the linkage between climatic records from meteorological station at lower to the higher elevation sites.

\section{ACKNOWLEDGEMENTS}

I express my sincere thanks to Department of Hydrology and Meteorology (DHM), Government of Nepal and EVK2 CNR, Italy for the use of their data. I also thank Prof. Dr. Eryuan Liang, Prof. Dr. Zhi-Yong Yin and anonymous reviewers for their constructive comments and Dr Pukar Man Amatya for his help to draw figure of the study area. This work is supported by Chinese Academy of Sciences Fellowship for Young International Scientists, Grant No 2014FFZB007.

\section{REFERENCES}

Anders, A. M., Roe, G. H., Hallet, B., Montgomery, D. R., Finnegan N. J., and Putkonen, J., 2006, Spatial patterns of precipitation and topography in the Himalaya. In Willett, S. D., Hovius, N., Brandon, M. T., and Fisher, D., (Eds.), Tectonics, Climate, and Landscape Evolution. Geol. Soc. America, Sp. Paper, v. 398, 39-53.

Barros, A. P., Joshi, M., Putkonen, J., and Burbank, D. W., 2000, A study of the 1999 monsoon rainfall in a mountainous region in central Nepal using TRMM products and rain gauge observations. Geophys. Res. Lett., v. 27(22), pp. 3683-3686.

Barros, A. P, Kim G., Williams, E., and Nesbitt, S. W., 2004, Probing orographic controls in the Himalayas during the monsoon using satellite imagery. Nat. Haz. Earth Sys. Sci., v. 4, pp. 29-51

Barry, R. G., 2008, Mountain Weather and Climate. Cambridge Univ. Press., $532 \mathrm{p}$.

Bookhagen, B., and Burbank, D. W., 2006, Topography, relief, and TRMM-derived rainfall variations along the Himalaya. Geophys. Res. Lett., v. 33, pp. 1-5.

Bradley, R. S., and Jones, P. D., (Eds.) 1992, Climate since A.D. 1500. Routledge, London, 679 p.

Böhner, J., 2006, General climatic controls and topoclimatic variations in Central and High Asia. Boreas, v. 35, pp. 279-295.

Cook, E. R., Krusic, P. J., and Jones, P. D., 2003, Dendroclimatic signals in long tree-ring chronologies from the Himalayas of Nepal. Int. Jour. Climatol., v. 23, pp. 707-732.

Dawadi, B., Liang, E., Tian, L., Devkota, L. P., and Yao, T., 2013, Premonsoon precipitation signal in tree rings of timberline Betula utilis in the central Himalayas. Quat. Int., v. 283, pp. 72-77.

Department of Hydrology and Meteorology, Kathmandu, 2007, Preliminary weather summary of Nepal. February Off weather Report. 1-4.

Dhar, O. N., and Nandargi, S., 2000, An appraisal of precipitation distribution around the Everest and Kanchenjunga peaks in the Himalayas. Weather, v. 55(7), pp. 223-234. 
Dhar, O. N., and Nandargi, S., 2005, Areas of heavy precipitation in the Nepalese Himalayas. Weather, v. 60(12), pp. 354-356.

Duncan, J. M. A., Biggs, E. M., Dash, J., and Atkinson, P., 2013, Spatio-temporal trends in precipitation and their implications for water resources management in climate-sensitive Nepal. Jour. Apl. Geog., v. 43, pp. 138-146.

Fritts, H. C., 1976, Tree-rings and climate. Academic Press, London, $567 \mathrm{p}$.

Fujita, K., Thompson, L. G., Ageta, Y., Yasunari, T., Kajikawa, Y., Sakai, A., and Takeuchi, N., 2006, Thirty-year history of glacier melting in Nepal Himalayas. Jour. Geophys. Res., v. 111, D03109.

Higuchi, K., Ageta, Y., Yasunari, T., and Inoue, J., 1982, Characteristics of precipitation during the monsoon season in high mountain areas of the Nepal Himalaya. In: Hydrological Aspects of Alpine and High-Mountain Areas (Ed. J. W. Glen): (Proc. Exeter Symp., July 1982), IAHS Publ. no. 138, 21-30.

Ichiyanagi, K., Yamanaka, M. D., Muraji, Y., and Vaidya, B. K., 2007, Precipitation in Nepal between 1987 and 1996. Int. Jour. Climtol., v. 27, pp. 1753-1762.

Kansakar, S. R., Hannah, D. M., Gerrard, J., and Rees, G., 2004, Spatial pattern in the precipitation regime of Nepal. Int. Jour. Climatol., v. 24, pp. 1645-1659.

Kattel, D. B., and Yao, T. D., 2013, Recent temperature trends at mountain stations on the southern slope of the central Himalayas. Jour. Earth Sys. Sci., v. 122(1), pp. 215-227.

Lang, T. J., and Barros, A. P., 2002, An Investigation of the Onsets of the 1999 and 2000 Monsoons in Central Nepal. Monthly weather Rev., v. 130, pp. 1299-1316.

Liang, E., Dawadi, B., Pederson, N., and Eckstien, D., 2014, Is the growth of birch at the upper timberline in the Himalayas limited by moisture or by temperature? Jour. Ecol., v. 95(9), pp. 24532465.

Liang, E., Liu, B., Zhu, L., and Yin, Y. Z., 2011, A short note on linkage of climatic records between a river valley and the upper timberline in the Sygera Mountains, southeastern Tibetan Plateau. Glob. Plan. Change, v. 77, pp. 97-102

Nayava, J. L., 1980, Rainfall in Nepal, The Himalayan Review. Nepal Geog. Soc., v. 12, pp. 1-18.

Pepin, N. C., and Norris, J. R., 2005, An examination of the differences between surface and free-air temperature trend at high-elevation sites: Relationships with cloud cover, snow cover, and wind.
Jour. Geophy. Res., v. 110, (D) 24112.

Putkonen, J. K., 2004, Continuous snow and rain data at 500 to 4400 m altitude near Annapurna, Nepal, 1999-2001. Arct. Ant. Alp. Res., v. 36(2), pp. 244-248.

Sano, M., Furuta, F., Kobayashi, O., and Sweda, T., 2005, Temperature variations since the mid- $18^{\text {th }}$ century for western Nepal, as reconstructed from tree-ring width and density of Abies spectabilis. Dendrochronologia, v. 23, pp. 83-92.

Sharma, E., Chettri N., Tsering, K., Shrestha, A. B., Fang, J., Mool, P., and Eriksson, M., 2009, Climate change impacts and vulnerability in the Eastern Himalayas. ICIMOD, Kathmandu, Nepal.

Shrestha, A. B., and Aryal, R., 2011, Climate change in Nepal and its impact on Himalayan glacier. Reg. Env. Change, v. 11, pp. $65-77$.

Shrestha, A. B., Wake, C. P., Mayewski, P. A., and Dibb, J. E., 1999, Maximum temperature trends in the Himalaya and its vicinity: an analysis based on temperature records from Nepal for the period 1971-94. Jour. Clim. Res., v. 12(9), pp. 2775-2786.

Shrestha, A. B., Wake, C. P., Dibb, J. E., and Mayewski, P. A., 2000, Precipitation fluctuations in Nepal Himalaya and its vicinity and relationship with some large scale climatological parameters. Int. Jour. Climatol. v. 20, pp. 317-327.

Shrestha, D., Singh, P., and Nakamura, K., 2012, Spatiotemporal variation of rainfall over the central Himalayan region revealed by TRMM Precipitation Radar. Jour. Geophys. Res., v. 117, D22106.

Shrestha, M. L., 2000, Interannual variation of summer monsoon rainfall over Nepal and its relation to Southern Oscillation Index. Met. Atmos. Phys., v. 75, pp. 21-28.

Shrestha, U. B., Gautam, S., and Bawa, K. S., 2012, Widespread Climate Change in the Himalayas and Associated Changes in Local Ecosystems. PLoS ONE, v. 7(5), e36741.

Singh, P., and Kumar, N., 1997, Effect of orography on precipitation in the western Himalayan region. Jour. Hydrol., v. 199, pp. 183206.

Ueno, K., and Aryal, R., 2008, Impact of tropical convective activity on monthly temperature variability during nonmonsoon season in the Nepal Himalayas. Jour. Geophys. Res., v. 113, D18112.

Yadav, R. R., Bräuning, A., and Singh, J., 2011, Tree ring inferred summer temperature variations over the last millennium in western Himalaya, India. Clim. Dyn., v. 36, pp. 1545-1554. 